\title{
ANALISIS PENGGUNAAN APLIKASI SISTEM INFORMASI LOGISTIK (SIL) UNTUK PERENCANAAN, PELAPORAN DAN PENGENDALIAN BERBASIS WEB DAN PENGARUHNYA TERHADAP KINERJA DAN KEPUASAN PENGGUNA (Studi pada : Pengguna Aplikasi SIL Perum Bulog Divisi Regional Jawa Timur)
}

\author{
Amma Fazizah, Eko Ganis Sukoharsono, Kertahadi \\ Fakultas Ilmu Administrasi, Universitas Brawijaya Malang \\ Email: ammafazizah@gmail.com
}

\begin{abstract}
Use of computer technology properly and optimally utilized by the BULOG Public Company. Perum Bulog utilizing information and communication technology to provide information related to inventory logistics and other operational activities. This study aimed to analyze the use of SIL applications for planning (X1), the use of SIL applications for reporting (X2) use SIL applications for logistics control (X3) and its effect on performance (Y1) and User Experience (Y2). The study is an explanatory reseach with survey approach. The object of the study is an user SIL applications. This study took place in Perum Bulog East Java Regional Division A. Yani 146-148 Jalan Surabaya. The sample are of to 88 users. Instruments in this study using a questionnaire with data analysis method using path analysis. Tools or software used in statistical data processing research was SPSS 20. Based on the results of the study, data analysis, and discussion of the results of study and testing hypotheses 7 are performed, there are six hypotheses were significant accepted, and the first hypothesis is rejected. Accepted hypothesis HI include the use of SIL applications for logistics planning has significant positive effect on user performance, H2 using a SIL applications for logistics planning significant positive effect on user satisfaction, H3 using a SIL applications for logistics reporting has significant positive effect on user performance, $H 4$ using a SIL applications for logistics planning no significant effect on user satisfaction, H5 using a SIL applications for logistics control has significant positive effect on user performance, H6 using a SIL applications for logistics control has significant positive effect on user satisfaction and user performance $H 7$ significant positive effect on user satisfaction.
\end{abstract}

Keywords : System Information Logistic, User Performance, User Experience

\begin{abstract}
ABSTRAK
Pemanfaatan teknologi komputer dengan baik dan optimal telah dimanfaatkan oleh Perum BULOG. Perum BULOG memanfaatkan teknologi informasi dan komunikasi untuk menyediakan informasi terkait persediaan logistik dan kegiatan operasional lainnya. Penelitian ini bertujuan untuk menganalisis penggunaan aplikasi SIL untuk perencanaan $\left(\mathrm{X}_{1}\right)$, penggunaan aplikasi SIL untuk pelaporan $\left(\mathrm{X}_{2}\right)$ penggunaan aplikasi SIL untuk pengendalian logistik $\left(\mathrm{X}_{3}\right)$ dan pengaruhnya terhadap kinerja $\left(\mathrm{Y}_{1}\right)$ dan Kepuasan Pengguna $\left(\mathrm{Y}_{2}\right)$. Jenis penelitian ini adalah penelitian eksplanatory reseach dengan melakukan pendekatan survey. Obyek analisis dalam penelitian ini adalah pengguna aplikasi SIL. Penelitian ini bertempat di PERUM BULOG Devisi Regional Jawa Timur Jalan A. Yani 146-148 Surabaya. Dengan sampel penelitian berjumlah 88 pengguna. Instrumen dalam penelitian ini menggunakan kuesioner dengan metode analisis data menggunakan path analysis. Tools atau Software yang digunakan dalam pengolahan data statistik penelitian adalah SPSS 20. Berdasarkan hasil penelitian, hasil analisis data, dan pembahasan hasil penelitian serta pengujian 7 hipotesis yang dilakukan, maka diperoleh hasil penelitian bahwa ada 6 hipotesis yang diterima, dan 1 hipotesis yang ditolak. Hipotesis yang diterima diantaranya $\mathrm{H} 1$ penggunaan aplikasi SIL untuk perencanaan logistik berpengaruh positif signifikan terhadap kinerja pengguna, $\mathrm{H} 2$ penggunaan aplikasi SIL untuk perencanaan logistik berpengaruh positif signifikan terhadap kepuasan pengguna, H3 penggunaan aplikasi SIL untuk pelaporan logistik berpengaruh positif signifikan terhadap kinerja pengguna, H4 penggunaan aplikasi SIL untuk perencanaan logistik tidak berpengaruh positif signifikan terhadap kepuasan pengguna, H5 penggunaan
\end{abstract}


aplikasi SIL untuk pengendalian logistik berpengaruh positif signifikan terhadap kinerja pengguna, H6 penggunaan aplikasi SIL untuk pengendalian logistik berpengaruh positif signifikan terhadap kepuasan pengguna, dan $\mathrm{H} 7$ kinerja pengguna berpengaruh positif signifikan terhadap kepuasan pengguna

\section{Kata Kunci : Sistem Informasi Logistik, Kinerja Pengguna, Kepuasan Pengguna}

\section{PENDAHULUAN}

Perkembangan ilmu pengetahuan dan fungsi berbagai jenis teknologi membuat dunia seperti tidak ada batasan. Kebutuhan manusia yang tidak terbatas menyebabkan timbulnya perubahan di dalam lingkungan masyarakat. Contoh salah satunya adalah kebutuhan akan pentingnya teknologi informasi. Seiring dengan pentingnya peran teknologi dalam sebuah organisasi, baik itu organisasi bisnis maupun organisasi publik, terutama di era sekarang menuntut semua perkerjaan menjadi serba cepat, praktis dan efisien.

Penerapan teknologi komputer diberbagai aspek kehidupan sudah menjadi suatu kebutuhan. Hal demikian dapat dirasakan dimana komputer sebagai hasil dari perkembangan teknologi banyak membantu mempermudah pekerjaan manusia menjadi efektif dan efisien, seperti mengumpulkan, memasukkan, mengolah, menyimpan dan mengirimkan data-data terkait dengan kejadian ekonomi yang disebabkan oleh kegiatan organisasi sehari-hari.

Salah satu aspek penting dalam reformasi birokrasi adalah penataan manajemen pemerintah pusat dan daerah. Hal tersebut penting antara lain karena keberhasilan suatu kebijakan ditentukan pula oleh kemampuan manajemen dalam birokrasi pemerintahan untuk melaksanakan kebijakan tersebut secara efisien dan efektif.

Salah satu hal yang mempengaruhi kinerja organisasi pemerintah adalah pemanfaatan TI. Perkembangan TI direspon oleh organisasi dengan mendesain sistem informasi berbasis teknologi komputer atau website. Sistem yang didukung TI dapat memberikan nilai tambah bagi organisasi jika didesain menjadi sistem informasi yang efektif

Pemanfaatan teknologi komputer dengan baik dan optimal telah dimanfaatkan oleh Badan Usaha Milik Negara yaitu Perusahaan Umum BULOG. Penggunaan aplikasi Sistem Informasi Logistik akan menyediakan informasi dengan kualitas yang lebih tinggi. Aktivitas aplikasi SIL yang kompleks biasanya diatur secara efektif karena kompleksitas mengharuskan adanya pengaturan, prosedur, dan dokumentasi yang efektif. Hal tersebut biasanya menghasilkan informasi yang kualitasnya lebih tinggi serta lebih cepat bagi manajemen perusahaan. Perum BULOG yakin bahwa informasi yang dihasilkan oleh aplikasi SIL dapat diandalkan, manajemen Perum BULOG akan menggunakan informasi tersebut untuk keputusan-keputusan manajemen yang lebih baik.

Dengan demikian harapan Perum BULOG dari adanya Software Sistem Informasi Logistik (SIL) ini memberikan kontribusi terhadap pencapaian kinerja pengguna yaitu menginformasikan laporan-laporan terkait dengan transaksi sehari-hari. Semua ini dapat terjadi bilamana para pegawainya mampu menciptakan kinerja yang optimal. Untuk mencapai kinerja pengguna secara optimal dapat diketahui dari beberapa indikator kinerja pengguna sebagai mana yang dijelaskan oleh Iqbaria dan Tan (1997) diantaranya : kinerja karyawan, produktivitas individu, kecepatan mengidentifikasi pekerjaan, pembuatan keputusan dari kinerja yang berkualitas, kecepatan mengidentifikasi masalah, kecepatan mengambil keputusan, dan tingkat analisis dalam mengambil keputusan. Dari beberapa indikator tersebut diharapkan pengguna memiliki kemampuan dalam menggunakan Software meliputi analisis data/informasi, mengevaluasi pekerjaan serta menyelesaikan pekerjaan dengan tepat waktu sehingga tidak menghambat proses penyampaian informasi kepada atasan. Apabila semua itu terwujud maka akan menciptakan kepuasan bagi pengguna. Berdasarkan uraian tersebut maka bisa dibayangkan implementasi yang muncul setelah Software Sistem Informasi Logistik (SIL) tersebut.

Wibowo (2004) dalam Elliyani (2009) melakukan penelitian untuk membuktikan secara empiris hubungan antara teknologi informasi dengan kinerja individual. Hasil penelitian menunjukkan bahwa pemanfaatan teknologi informasi berpengaruh secara signifikan terhadap kinerja individual, sedangkan kesesuaian tugas 
dan teknologi tidak berpengaruh secara signifikan terhadap kinerja individual.

Kajian empiris mengenai pengukuran kepuasan pengguna e-commerce oleh Schaupp, et al (2009) "Examining the Success of Websitess Beyond ecommerce". Schaupp, et al telah mengukur kepuasan pengguna e-commerce melalui sistem pendukung informasi (information success system) model dari Delon and MacLean dengan memasukkan variabel Kualitas sistem, Kualitas informasi dan Norma

Subyektif sebagai variabel bebas, sebagai variabel moderator Individual Impact dan Website Satisfaction sebagai variabel terikat. Hasil penelitian menunjukkan bahwa kepuasan pengguna tidak dapat diukur hanya dengan menggunakan satu tolak ukur saja, seperti menggunakan variabel Kualitas Sistem dan variabel Kualitas Informasi secara terpisah. Jalur kualitas informasi dan individual impact menunjukkan hasil yang signifikan antara keduanya. Jalur Kualitas informasi dan website satisfaction tidak ditemukan hasil yang signifikan. Kualitas sistem dan individual impact menunjukkan hasil yang signifikan pada website online community akan tetapi hasilnya tidak signifikan pada website online e-commerce. Jalur kualitas sistem dan website satisfaction menunjukkan hasil yang signifikan. Begitu pula pada jalur subjective norm dan individual impact juga menunjukkan hasil yang signifikan.

Hossain, Moon, Yun , dan Cho, (2011) dalam penelitiannya Dampak Psikologis Pengguna Layanan Sistem Informasi Pelanggan terhadap Kinerja, yang mengembangkan model untuk menilai kinerja pengguna sistem informasi di sebuah organisasi dalam menyediakan layanan pelanggan. Dari hipotesis yang dikembangkan mengenai interaksi kepuasan sistem, lingkungan kerja organisasi dengan sifat-sifat psikologis pengguna dan bagaimana interaksi ini mempengaruhi kinerja. Hasil analisis menunjukkan peran sifat-sifat psikologis pengguna dan lingkungan organisasi sangat penting dalam membangun kinerja.

Penggunaan teknologi informasi di Perum BULOG merupakan sebuah kondisi dimana pemahaman dan keterampilan memanfaatkan teknologi informasi dalam meningkatkan kinerja dan kepuasan pengguna sangat dibutuhkan. Dalam rangka pencapaian penggunaan teknologi informasi di Perum BULOG ini maka harus mengembangkan persepsi, komitmen dalam rangka mendorong setiap anggota organisasi (pegawai) berinteraksi, mengaplikasikan teknologi informasi dan memanfaatkannya dalam melaksanakan tugas sehari-hari.

Dari permasalahan yang telah digambarkan di atas, bahwa demi kesuksesan pembangunan nasional guna mewujudkan visi dan misi PERUM BULOG dibutuhkan teknologi sistem informasi yang dapat meningkatkan kinerja pegawai. Penelitian ini bertujuan menganalisis penggunaan Sistem Informasi Logistik (SIL) di kegiatan perencanaan, pelaporan dan pengendalian logistik berbasis web dan pengaruhnya terhadap kinerja dan kepuasan pengguna studi pada pengguna Sistem Informasi Logistik.

\section{LATAR BELAKANG TEORI DAN HIPOTESIS \\ Tinjauan Empiris dan Teoritis}

Dijelaskan dalam penelitian Evi Herawati (2008) mengenai Penggunaan aplikasi Sistem Informasi untuk persediaan pada PT.SS menunjukkan bahwa aplikasi sistem informasi persediaan yang digunakan perusahaan PT. SS telah memadai dan dapat memberikan informasi yang handal dan tepat waktu sehingga mempermudah manajemen dalam mengambil suatu keputusan yang berkaitan dengan kebijakan persediaan sehingga bisa membentuk kinerja pengguna yang optimal.

Adapun penelitian dari Oswari (2008) mengenai dampak penggunaan teknologi inormasi untuk pelaporan terhadap kinerja pelaku UKM, yang mana penggunaan teknologi informasi oleh pelaku UKM mempunyai pengaruh yang nyata, khususnya pada pembuatan laporan keuangan.

Studi dari Ilma dan Sukoharsono (2011) mengenai Analisis penggunaan internet untuk pelaporan bisnis dengan pendekatan media kekayaan pada Perusahaan Pertambangan yang terdaftar di BEI. Temuan penelitian ini menunjukkan bahwa Fitur dari internet sangat bermanfaat sebagai media komunikasi pelaporan kegiatan bisnis dan bisa meningkatkan proses kualitas komunikasi di lingkungan perusahaan dengan stakeholder.

Dijelaskan dalam Kuang Hou (2012) dalam penelitiannya yang meneliti pengaruh kepuasan pengguna pada penggunaan sistem dan kinerja 
individu dengan sistem intelijen bisnis : studi empiris dari industri elektronik Taiwan. Penelitian ini bertujuan untuk menguji secara empiris hubungan antara end-pengguna computing satisfaction (EUCS), penggunaan sistem dan kinerja individu. Data dikumpulkan dari 330 pengguna akhir sistem BI di industri elektronik Taiwan yang digunakan untuk menguji hubungan yang diusulkan dalam rangka menggunakan pendekatan pemodelan persamaan struktural. Hasil penelitian menunjukkan EUCS dapat menyebabkan peningkatan penggunaan sistem BI dan peningkatan kinerja individu, dan penggunaan sistem $\mathrm{BI}$ akan mengarah ke tingkat kinerja individu. Selain itu, temuan studi ini mengembangkan penelitian dari model IS DeLone dan MacLean, yang mengkonfirmasi bahwa ada hubungan positif antara EUCS dan penggunaan sistem.

Ristianti dan Sukoharsono (2012) menjelaskan dalam penelitiannya mengenai Enterprise Resource Planning (ERP) Sistem Analisis Implementasi Berbasis Web untuk perencanaan dan pengendalian manajemen di PT. Anugrah Jasa Caterindo. Hasil penelitiannya menunjukkan bahwa Sistem ERP sangat mendukung dan memfasilitasi kegiatan operasional PT AJC sehingga bisa menjaga perencanaan dan pengendalian manajemen. Akan tetapi sistem ERP belum sepenuhnya dilaksanakan oleh PT AJC. Hal ini terutama diterapkan untuk kegiatan dan tujuan operasional. Penerapan sistem ERP untuk kegiatan operasional PT AJC dirasa cukup baik, karena ketersediaan dari tiga elemen dasar dari sistem, yaitu: komponen fisik, sumber daya manusia, organisasi, atau proses industri.

Studi dari Limbu, et al (2014) dalam penelitiannya yang bertujuan untuk mengetahui apakah teknologi informasi dan komunikasi bisa meningkatkan kepuasan pengguna, Hasil penelitian menunjukkan bahwa Information Comunication Technology (ICT) secara tidak langsung mempengaruhi kepuasan kerja melalui kinerja administrasi Salesforce. Sementara infrastruktur ICT, pelatihan, dan dukungan positif berhubungan dengan administrasi kinerja.

Sistem Informasi Logistik (SIL)

Logistik merupakan sebuah seni dan ilmu bagaimana tata cara mengelola, mengevaluasi kegiatan material, barang, informasi dan sumber daya lain seperti barang, jasa, maupun manusia dari sumber-sumber produksi yang ada menuju pasar.
Sistem Informasi Logistik merupakan bagian dari suatu instansi yang mana menyediakan material yang dibutuhkan untuk kegiatan operasional suatu instansi tersebut dalam hal jumlah, kualitas dan waktu yang tepat dengan biaya yang serendah-rendahnya (Hartono:2005)

Berdasarkan Pedoman Umum Pengadaan Beras diDalam Negeri Tahun 2005 Perum BULOG, Pengertian Sistem Informasi Logistik Yaitu : "Software atau aplikasi yang memanfaatkan teknologi informasi dan komunikasi untuk kegiatan perencanaan, pelaporan dan pengendalian logistik serta memfasilitasi kegiatan operasional BULOG untuk mencapai tujuan perusahaan".

\section{Kinerja Pengguna}

Kinerja pengguna adalah fungsi dari interaksi antara kemampuan dan motivasi dalam menggunakan sebuah teknologi informasi. Adapun indikator/item dari kinerja pengguna dalam Iqbaria dan Tan (1997) yang nantinya akan digunakan dalam penelitian ini diantaranya :

1. Job performance (kinerja dari pekerjaan)

2. Individual productivity (produktivitas individu)

3. Job effectiveness (kecepatan mengidentifikasi pekerjaan)

4. Decision making quality (pembuatan keputusan kinerja yang berkualitas)

5. Problem identification speed (kecepatan mengidentifikasi masalah)

6. Decision making speed (kecepatan pengambilan keputusan)

7. The extent of analysis in decision making (tingkat analisis dalam pengambilan keputusan).

\section{Kepuasan Pengguna}

Kepuasan pengguna terhadap bentuk sistem teknologi informasi adalah cara pengguna memandang sistem teknologi informasi secara nyata, tidak pada kualitas sistem secara teknik (Guimaraes, Staples, dan McKeen, 2003). Dalam penelitian Kuang Hou (2012) menyatakan bahwa terdapat lima instrumen dalam pengukuran sebuah kepuasan pengguna atas penggunaan suatu sistem informasi, yang didapatkan dari pengguna akhir sistem informasi, dimana lima item tersebut meliputi :
1. Isi (Content)
2. Akurasi system (Accuracy)
3. Format (Format) 
4. Kemudahan dalam penggunaan teknologi (Perceived Ease of Use)

5. Ketepatan waktu (Timesline)

\section{METODE PENELITIAN \\ Model Konseptual}

Berdasarkan uraian dari latar belakang, rumusan masalah, tujuan penelitian, uraian teoritis, dan hasil penelitian terdahulu, gambaran variabelvariabel penelitian dan hubungan antar variabelvariabel, sebagaimana ditunjukkan pada gambar 1.

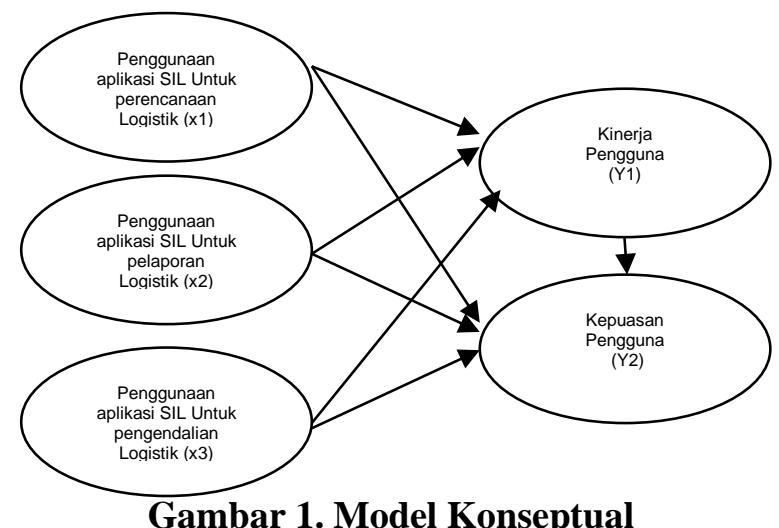

\section{METODE PENELITIAN}

Jenis penelitian yang digunakan dalam penelitian ini adalah penelitian survey, yaitu menggunakan kuesioner sebagai alat pengambilan data. Obyek analisis dalam penelitian ini adalah pengguna SIL di PERUM BULOG Divre Jatim. Penelitian ini bertempat di Perum BULOG Devisi Regional Jawa Timur Jalan Ahmad Yani 146 - 148 Surabaya.

a. Populasi dan sampel

Populasi dan sampel dalam penelitian ini adalah pengguna aplikasi SIL. Populasi sejumlah 113 pengguna dan penentuan jumlah sampel dengan menggunakan rumus Solvin sebesar 88 Pengguna.

b. Teknik pengambilan sampel menggunakan metode pengambilan sampel Cluster Sampling. Metode Cluster Sampling adalah teknik pengambilan sampel dimana pemilihannya mengacu pada kelompok bukan pada individu. Cara seperti ini baik sekali untuk dilakukan apabila tidak terdapat atau sulit menentukan/menemukan kerangka sampel, meski dapat juga dilakukan pada populasi yang kerangka sampelnya sudah ada (Sugiyono, 2012). c. Metode analisis data, menggunakan analysis yaitu Model Path Analysis dimanfaatkan untuk menganalisis pola hubungan antar variabel yang bertujuan untuk mengetahui pengaruh langsung dan tidak langsung dari variabel eksogen terhadap variabel endogen (Riduwan dan Kuncoro, 2011:116).

d. Instrumen Penelitian dan Skala Pengukuran, Instrumen dalam penelitian ini menggunakan instrumen kuesioner, Untuk keperluan analisis kuantitatif, jawaban responden diberi skor dengan menggunakan skala Likert yang memakai opsi 1-5.

e. Uji Validitas dan Uji Reliabilitas

Sebelum kuesioner disebarkan kepada responden, sebelumnya peneliti telah melakukan uji pilot tes secara acak terhadap 20 Mahasiswa Program Magister Administrasi Bisnis Fakultas Ilmu Administrasi UB. Hasil uji validitas pilot tes yang diperoleh dari pengujian terhadap item-item kuesioner disajikan adalah valid, Pengujian dilakukan pada taraf $\alpha=0,05$. Dari hasil uji reliabilitas diketahui bahwa nilai reliabilitas yang dicapai pada masing-masing variabel diperoleh nilai dari semua variabel lebih besar dari 0,6. Dengan demikian instrumen yang digunakan dalam penelitian ini dapat dikatakan reliabel dan handal sebagai alat ukur. Sehingga angket penelitian bisa disebarkan kepada responden.

Begitupun dengan hasil uji validitas penelitian terhadap item-item kuesioner yang berjumlah 18 item yang disajikan adalah valid, Pengujian dilakukan pada taraf $\alpha=0,05$. Dari hasil uji reliabilitas penelitian diketahui bahwa nilai reliabilitas yang dicapai pada masingmasing variabel diperoleh nilai dari semua variabel lebih besar dari 0,6. Dengan demikian instrumen yang digunakan dalam penelitian ini dapat dikatakan reliabel dan handal sebagai alat ukur. Sehingga angket penelitian bisa disebarkan kepada responden.

\section{HASIL DAN PEMBAHASAN ANALISIS DATA}

\section{Hasil Pengujian Asumsi Klasik}

Pengujian asumsi klasik adalah pengujian mengenai asumsi statistik yang harus dipenuhi dengan analisis regresi berganda yang berbasis Ordinary Least Square (OLS). Uji asumsi klasik yang digunakan dalam penelitian ini adalah uji normalitas, dan uji linieritas.

Uji normalitas dilakukan dengan menggunakan uji Kolmogorov-Smirnov dimana 
dengan memperhatikan hasil nilai signifikansi (sig.Z) tiap persamaan yang ada apakah lebih besar dari nilai $\alpha 0,05$. Hasil pengujian tersebut adalah tersaji pada sebagai berikut

Tabel 1. Hasil Uji Normalitas

\begin{tabular}{|c|c|c|}
\hline Persamaan & $\begin{array}{c}\text { Kolmogorov- } \\
\text { Smirnov Z }\end{array}$ & Sig \\
\hline $\begin{array}{c}\text { Persamaan } \\
\text { Pertama }\end{array}$ & 1.177 & 0.125 \\
\hline Persamaan Kedua & 1.265 & 0.082 \\
\hline
\end{tabular}

Sumber : Data Primer diolah (lampiran 7 hal 198), 2014.

Tabel 1. di atas dapat disimpulkan bahwa residual persamaan satu dan persamaan dua berdistribusi normal. Hal ini dikarenakan nilai signifikansi tiap persamaan lebih besar dari $\alpha=$ 0,05 , yaitu dari persamaan satu sebesar 0.125 dan persamaan dua 0.082

\section{Hasil Analisis Jalur \\ Analisis Jalur Persamaan Pertama}

Analisis jalur dilakukan pada persamaan pertama digunakan untuk menganalisis pengaruh langsung antara variabel penggunaan aplikasi SIL untuk perencanaan logistik $\left(\mathrm{X}_{1}\right)$, variabel penggunaan aplikasi SIL untuk pelaporan logistik $\left(\mathrm{X}_{2}\right)$, variabel penggunaan aplikasi SIL untuk pengendalian logistik $\left(\mathrm{X}_{3}\right)$ terhadap variabel kinerja pengguna $\left(\mathrm{Y}_{1}\right)$.

Tabel 2. Hasil Uji Linieritas

Sumber : Data Primer diolah, 2014.
Hasil regresi model persamaan pertama adalah $\mathrm{Y}_{1}=0.404 \mathrm{X}_{1}+0.592 \mathrm{X}_{2}+0.600 \mathrm{X}_{3}+\mathrm{e}$. Berdasarkan analisis jalur model pertama hubungan langsung antara $\mathrm{X}_{1}$ terhadap $\mathrm{Y}_{1}$ adalah sebesar 0,404, hubungan antara $\mathrm{X}_{2}$ terhadap $\mathrm{Y}_{1}$ adalah sebesar 0,592 dan hubungan antara $X_{3}$ terhadap $Y_{1}$ sebesar 0.600 , kedua nilai beta dari hubungan lansung antara $X_{1}, X_{2}$ terhadap $Y_{1}$ mengandung nilai signifikansi di atas $\alpha(0,05)$ yaitu masing-masing 0,001 dan 0,000 dan nilai beta untuk hubungan antar $\mathrm{X}_{3}$ terhadap $\mathrm{Y}_{1}$ mengandung nilai signifikansi di bawah $\alpha(0,05)$ yaitu 0.000. Nilai error dihitung dengan ei $=1$ $R_{2}{ }^{2}$, dari rumus tersebut diperoleh nilai 0.21 .

\section{Analisis Jalur Persamaan Kedua}

Analisis jalur dilakukan pada persamaan kedua digunakan untuk menganalisis pengaruh langsung antara variabel penggunaan aplikasi SIL untuk perencanaan logistik $\left(\mathrm{X}_{1}\right)$, variabel penggunaan aplikasi SIL untuk pelaporan logistik $\left(\mathrm{X}_{2}\right)$, variabel penggunaan aplikasi SIL untuk pengendalian logistik $\left(\mathrm{X}_{3}\right)$ dan Kinerja Pengguna $\left(\mathrm{Y}_{1}\right)$ terhadap Kepuasan Pengguna $\left(\mathrm{Y}_{2}\right)$.

\section{Tabel 3. Hasil Uji Linieritas}

\begin{tabular}{|c|c|c|c|c|c|c|}
\hline $\begin{array}{c}\text { Variabel } \\
\text { Bebas }\end{array}$ & $\begin{array}{l}\text { Variabel } \\
\text { Terlkat }\end{array}$ & B & Beta & $\mathrm{t}$ & silg & Keterangan \\
\hline Const & - & 1.302 & - & 0.854 & 0.395 & - \\
\hline $\begin{array}{l}\text { Penggunasn } \\
\text { Ap Kasl SIL } \\
\text { untuk } \\
\text { Perencanasn } \\
\left.\text { Loglistk ( } X_{4}\right)\end{array}$ & $\begin{array}{l}\text { Kepuasan } \\
\text { Pengguna }\left(\gamma_{\hat{A}}\right)\end{array}$ & 0.456 & 0.237 & 2.269 & 0.026 & Signitikan \\
\hline 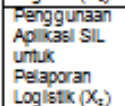 & $\begin{array}{l}\text { Kepuasan } \\
\text { Pengguna }\left(\gamma_{2}\right)\end{array}$ & 0.198 & 0.201 & 0.835 & 0.405 & Tidak Significan \\
\hline $\begin{array}{l}\text { Ponggunas } \\
\text { Ap kasi SIL } \\
\text { untuk } \\
\text { Pengendallan } \\
\text { Loglistk }\left(X_{3}\right)\end{array}$ & $\begin{array}{l}\text { Kepuasan } \\
\text { Pengguna }\left(\gamma_{2}\right)\end{array}$ & 0.990 & 0.423 & 2.341 & 0.022 & Signitican \\
\hline $\begin{array}{l}\text { Raneria } \\
\text { Pengguna } \\
\left(Y_{i}\right)\end{array}$ & $\begin{array}{l}\text { Kepuasan } \\
\text { Pengguna }\left(\gamma_{2}\right)\end{array}$ & 0.326 & 0.862 & 3.991 & 0.000 & Significan \\
\hline $\mathrm{R}$ & -0.899 & & & & & \\
\hline $\mathrm{R}^{*}$ & -0.704 & & & & & \\
\hline $\begin{array}{l}\text { umberdys } \\
\text { F nitun }\end{array}$ & 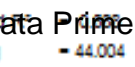 & & & 014. & & \\
\hline
\end{tabular}

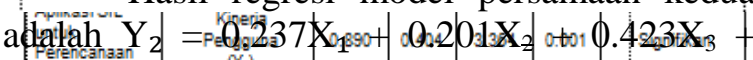
$08882 Y_{1}+$ e. "Berdasarkan analisis jalur model

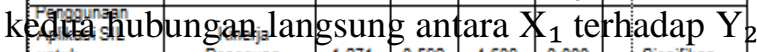

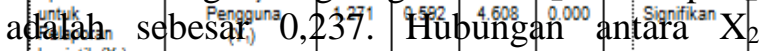

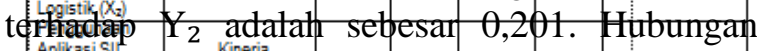

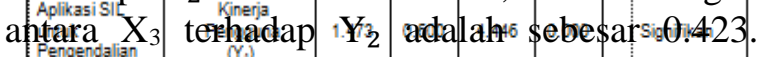
Hübunirgan antara $Y_{1}$ dengan $Y_{2}$ adalah sebesar $0882_{R}$ Nilai=obeta dari $\mathrm{X}_{1}$ terhadap $\mathrm{Y}_{2}$ mengẳndung nîlââ4 signifikansi di bawah $\alpha(0,05)$

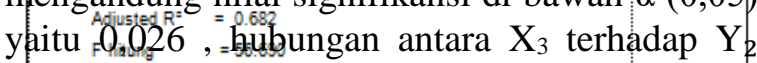
mengâñoung =nillai signifikansi di bawah $\alpha(0,05)$ yaitu 0,022 dan hubungan antara $Y_{1}$ dengan $Y_{2}$ mengandung nilai signifikansi di bawah $\alpha(0,05)$ 
yaitu masing 0,000 . Nilai error dihitung dengan ei $=1-R_{2}{ }^{2}$, dari rumus tersebut diperoleh nilai 0.22

Berdasarkan hasil analisis jalur tiap persamaan, maka dapat digambarkan model hasil analisis jalur secara keseluruhan dalam tabel dibawah ini :

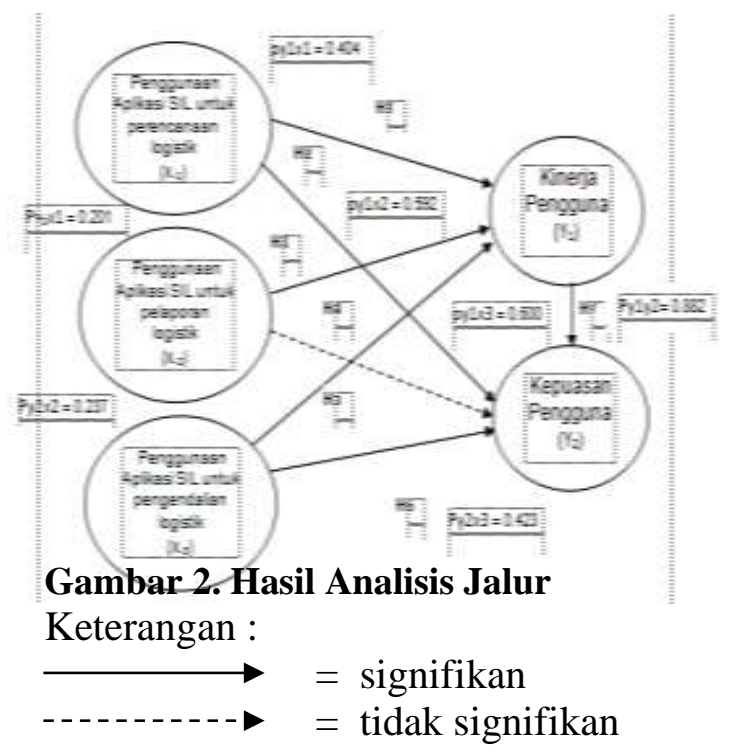

\section{Hasil Pengujian Hipotesis}

Dasar pengambilan keputusan untuk pengujian hipotesis digunakan nilai signifikasi (sig. t) dengan kriteria apabila sig. $t>0,05$, maka H0 diterima Ha ditolak, artinya koefisien jalur yang diperoleh adalah tidak signifikan. Dan apabila sig $\mathrm{t}<0,05$ maka $\mathrm{H} 0$ ditolak atau Ha diterima, artinya koefisien jalur yang diperoleh adalah signifikan.

\section{Pengujian Hipotesis $\mathrm{H}_{1}$}

Hipotesis $\mathrm{H}_{1}$ menyatakan bahwa terdapat pengaruh positif signifikan dari penggunaan aplikasi SIL untuk perencanaan logistik terhadap kinerja pengguna, dengan koefisien jalur pada hubungan ini sebesar 0,404 dengan signifikansi ( $\mathrm{sig}, \mathrm{t}=0,001)$, sehingga dapat disimpulkan bahwa data penelitian ini mendukung hipotesis $\mathrm{H}_{1}$, penggunaan aplikasi SIL untuk perencanaan logistik positif meningkatkan kinerja pengguna.

\section{Pengujian Hipotesis $\mathbf{H}_{2}$}

Hipotesis $\mathrm{H}_{2}$ menyatakan bahwa terdapat pengaruh positif signifikan dari penggunaan aplikasi SIL untuk perencanaan logistik terhadap kepuasan pengguna, dengan koefisien jalur pada hubungan ini sebesar 0.237 dengan signifikansi $(\mathrm{sig}, \mathrm{t}=0,026)$, sehingga dapat disimpulkan bahwa data penelitian mendukung hipotesis $\mathrm{H}_{2}$, penggunaan aplikasi SIL untuk perencanaan logistik positif meningkatkan kepuasan pengguna.

\section{Pengujian Hipotesis $\mathrm{H}_{3}$}

Hipotesis $\mathrm{H}_{3}$ menyatakan bahwa terdapat pengaruh positif signifikan dari penggunaan aplikasi SIL untuk pelaporan logistik terhadap kinerja pengguna, dengan koefisien jalur pada hubungan ini sebesar 0.592 dengan signifikansi $(\mathrm{sig}, \mathrm{t}=0,000)$, sehingga dapat disimpulkan bahwa data penelitian mendukung hipotesis $\mathrm{H}_{3}$, penggunaan aplikasi SIL untuk pelaporan logistik meningkatkan kinerja pengguna.

\section{Pengujian Hipotesis $\mathrm{H}_{4}$}

Hipotesis $\mathrm{H}_{4}$ menyatakan bahwa terdapat pengaruh yang tidak signifikan dari penggunaan aplikasi SIL untuk pelaporan logistik terhadap kepuasan pengguna, dengan koefisien jalur pada hubungan ini sebesar 0,201 dengan signifikansi (sig, $\mathrm{t}=0,406$ ), sehingga dapat disimpulkan bahwa data penelitian tidak mendukung hipotesis $\mathrm{H}_{4}$, penggunaan aplikasi SIL untuk pelaporan logistik dalam penelitian ini tidak akan bisa meningkatkan kepuasan pengguna.

\section{Pengujian Hipotesis $\mathrm{H}_{5}$}

Hipotesis $\mathrm{H}_{5}$ menyatakan bahwa terdapat pengaruh positif signifikan dari penggunaan aplikasi SIL untuk pengendalian logistik terhadap kinerja pengguna, dengan koefisien jalur pada hubungan ini sebesar 0,600 dengan signifikansi (sig, $\mathrm{t}=0,000)$, sehingga dapat disimpulkan bahwa data penelitian mendukung hipotesis $\mathrm{H}_{5}$, penggunaan aplikasi SIL untuk pengendalian logistik yang lebih baik akan meningkatkan kinerja pengguna secara langsung.

\section{Pengujian Hipotesis $\mathrm{H}_{6}$}

Hipotesis $\mathrm{H}_{6}$ menyatakan bahwa terdapat pengaruh positif signifikan dari penggunaan aplikasi SIL untuk pengendalian logistik terhadap kepuasan pengguna, dengan koefisien jalur pada hubungan ini sebesar 0.423 dengan signifikansi (sig, $\mathrm{t}=0,000)$, sehingga dapat disimpulkan bahwa data penelitian mendukung hipotesis $\mathrm{H}_{6}$, karena nilai sig. $\mathrm{t}$ melebihi 0,05. Dapat disimpulkan penggunaan aplikasi SIL untuk pengendalian logistik yang digunakan di Perum BULOG sangat berdampak besar terhadap peningkatan kepuasan pengguna. 


\section{Pengujian Hipotesis $\mathbf{H}_{7}$}

Hipotesis $\mathrm{H}_{7}$ menyatakan bahwa terdapat pengaruh positif signifikan dari kinerja pengguna terhadap kepuasan pengguna, dengan koefisien jalur pada hubungan ini sebesar 0.882 dengan signifikansi (sig, $\mathrm{t}=0,000$ ), sehingga dapat disimpulkan bahwa data penelitian sangat mendukung hipotesis $\mathrm{H}_{7}$, karena nilai sig. $\mathrm{t}$ melebihi 0,05. Dapat disimpulkan bahwa kinerja pengguna aplikasi SIL di Perum BULOG sangat berdampak besar terhadap peningkatan kepuasan pengguna.

\section{Keterbatasan Penelitian}

a. Penyebaran kuesioner hanya bisa dititipkan pada Divisi HRD/SDM Perum BULOG yang bertempat di Jl. A. Yani 146-148 Surabaya. Hal ini dikarenakan wilayah penelitian yang luas dalam satu provinsi Jawa Timur, HRD Perum BULOG menyarankan agar penyebaran kuesioner dikoordinir oleh HRD dengan menyertakan surat instruksi dari Kepala Divre, bahwasanya pengguna diwajibkan mengisi kuesioner yang ada. Penyebaran kuesioner sebagai perangkat utama penelitian yang dilakukan pada waktu jam kerja, maka sangat dimungkinkan untuk menggunakan instrumen lain seperti wawancara mendalam untuk menggali lebih lanjut informasi dan gambaran pengaruh variabel-variabel yang dihipotesiskan dalam penelitian dengan maksimal.

b. Penelitian ini dilakukan pada jangka waktu yang singkat, sehingga tidak mampu menggambarkan dinamika objek yang diteliti bila dibandingkan dengan penelitian dalam jangka waktu yang lebih lama. Hal ini dikarenakan juga aturan di Perum BULOG yang memberikan tenggang waktu tertentu untuk proses pengambilan data.

c. Penelitian ini dilakukan pada salah satu Divre saja, yaitu Divre Jawa Timur. Sehingga hasil penelitian tidak mampu menggambarkan dinamika objek yang diteliti secara makro. Hasil penelitian juga tidak bisa mempengaruhi kebijakan organisasi ini, mengingat Perum BULOG adalah salah satu BUMN di Indonesia.

d. Variabel bebas yang digunakan dalam penelitian ini hanya variabel Penggunaan aplikasi Sistem Informasi Logistik (SIL) saja, sehingga masih bisa dikembangkan dengan variabel yang lain yang dapat mempengaruhi kinerja dan kepuasan pengguna, misalnya penggunaan aplikasi Sistem Informasi Akuntansi BULOG (SIAB)

\section{KESIMPULAN DAN SARAN Kesimpulan}

Ditemukan Pengaruh positif signifikan dari Penggunaan Aplikasi SIL untuk Perencanaan Logistik terhadap Kinerja Pegguna. Hal ini menunjukkan persepsi pengguna menyetujui bahwasanya secara keseluruhan penggunaan aplikasi SIL untuk perencanaan logistik wajib digunakan setiap hari di jam kerja, karena sangat membantu pekerjaan pengguna untuk menyajikan informasi terkait dengan transaksi-transaksi yang ada dalam menjaga kebutuhan logistik di Perum BULOG.

Ditemukan pengaruh positif signifikan dari Penggunaan Aplikasi SIL untuk Perencanaan Logistik terhadap kepuasan pengguna, Hal ini berarti bahwa kepuasan pengguna akan semakin tinggi apabila diiringi dengan kemampuan sistem yang ada, kemampuan sistem melebihi harapan yang diterima oleh pengguna sehingga penerimaan sistem informasi oleh pengguna tersebut semakin meningkat.

Ditemukan pengaruh positif signifikan dari Penggunaan Aplikasi SIL untuk Pelaporan Logistik terhadap kinerja pengguna, ini berarti bahwa penggunaan aplikasi SIL untuk pelaporan logistik dengan intensitas/frekuensi yang tinggi dalam bekerja sehari-hari sangat mempengaruhi kinerja pengguna secara penuh. Pengguna bisa menyajikan laporan kepada atasan dengan praktis dan cepat.

Ditemukan pengaruh yang tidak signifikan dari Penggunaan Aplikasi SIL untuk Pelaporan Logistik terhadap kepuasan pengguna, ini berarti bahwa Kinerja pengguna dalam menghasilkan laporan tersebut akan tercapai apabila kesesuaian tugas dan manfaat dari teknologi informasi dapat memenuhi kebutuhan pengguna dalam menyelesaikan tugas kerjanya yang berkaitan dengan pelaporan logistik secara berkala kepada atasan. Namun disini ditemukan pengguna tidak merasa puas dengan timesline sistem yang ada dikarenakan padatnya lalu lintas data dalam periode waktu tertentu, dimana pengguna harus bisa memberikan laporan terkait dengan transaksi-transaksi yang ada.

Ditemukan pengaruh positif signifikan dari Penggunaan Aplikasi SIL untuk Pengendalian Logistik terhadap kinerja pengguna, Hal ini menunjukkan persepsi pengguna menyetujui bahwa secara keseluruhan 
pengguna setuju penggunaan aplikasi SIL untuk pengendalian logistik wajib digunakan setiap hari di jam kerja, karena sangat membantu pekerjaan pengguna untuk menangani transaksi yang komplek dalam jumlah besar dengan efisien, sehingga bisa mengurangi salah saji dengan mengganti prosedur yang biasanya dilakukan secara manual dengan pengendalianpengendalian yang terprogram yang menerapkan fungsi saling mengawasi dan mengontrol (check and balance) untuk setiap transaksi yang diproses.

Ditemukan pengaruh positif signifikan dari Penggunaan Aplikasi SIL untuk Pengendalian Logistik terhadap kepuasan pengguna, Hal ini menunjukkan bahwa akurasi system aplikasi SIL bisa menghasilkan informasi yang dibutuhkan oleh pengguna dalam waktu yang cepat.

Ditemukan pengaruh positif signifikan dari kinerja pengguna terhadap kepuasan pengguna, Hal ini berarti bahwa dengan adanya aplikasi Sistem Informasi Logistik (SIL) tersebut kinerja pengguna efektif dan efisien, sehingga mempengaruhi kepuasan pengguna untuk menggunakan aplikasi SIL secara berkelanjutan sebagai alat bantu yang bisa memenuhi kebutuhan kerja dalam pekerjaan pengguna sehari-hari.

\section{Saran}

Dari hasil penelitian, diajukan beberapa saran yang bisa digunakan sebagai bahan pertimbangan bagi peneliti lain dalam bidang pengembangan sistem informasi yang akan melakukan penelitian lanjutan dan kebijakan praktis bagi Perum BULOG, adalah sebagai berikut:

\section{Penelitian Selanjutnya}

a. Mengembangkan variabel-variabel bebas lain yang dapat mempengaruhi kinerja dan kepuasan pengguna. Misalnya penggunaan aplikasi Sistem Informasi Akuntansi BULOG (SIAB). Hal ini sejalan dengan beberapa referensi dari penelitian-penelitian terdahulu yang digunakan sebagai acuan dan perbandingan dalam penelitian ini.

b. Penambahan jumlah sampel akan memberikan hasil yang berbeda pada hasil penelitian. Karena dengan sampel yang lebih banyak akan terdapat banyak kemungkinan temuan penelitian terbaru yang berguna bagi acuan penelitian-penelitian di masa yang akan datang.

\section{Praktis}

Perum BULOG Divre Jawa Timur lebih memfokuskan perhatian yang terkait dengan penggunaan aplikasi SIL untuk membantu meningkatkan kinerja pengguna sehari-hari. Hal ini agar berbanding lurus peningkatannya dengan kepuasan pengguna. Mengingat aplikasi SIL dalam penelitian ini digunakan oleh pengguna dalam satu wilayah Divre/satu Provinsi. Kedua hal tersebut harus ditingkatkan lagi pengendalian sistemnya oleh Perum BULOG karena diketahui berpengaruh signifikan terhadap kinerja pengguna, namun tidak berpengaruh signifikan terhadap kepuasan pengguna sehingga masih perlu diperhatikan hal-hal terkait kepuasan kerja pengguna.

Evaluasi kinerja aplikasi SIL oleh Technical Support diharapkan lebih intens kurang dari 1 bulan, sebagaimana yang selama ini ada, evaluasi kinerja aplikasi SIL dilakukan oleh technical support selama 1 bulan sekali dan apabila ada keluhan dari pengguna.

\section{DAFTAR PUSTAKA}

Arikunto, S. 2010. Prosedur Penelitian : Suatu Pendekatan Praktik (Edisi Revisi), Jakarta. Rineka Cipta.

Davis, F.D, Bagozzi. R. P. \& Warshaw. P. R. 1989. Pengguna acceptance of computer technology : a comparison of two theoretical models, Management Science, 35, 982-1003.

Elliyani, Redi Hamzah. 2009. Variabel Anteseden \& konsekuensi Pemanfaatan SI. Jurnal Akuntansi dan Keuangan Indonesia. Vol-6 Nomor 1.

Eriyanto. 2007. Analisis Framing. Yogyakarta. LKIS Yogyakarta.

Ferdinand, A. T. 2006. Metode Penelitian Manajemen. BP Undip. Semarang

Guimaraes, T., D. S. Staples, dan J. D. Keen. (2003) Empirically Testing Some Main User Related Factor for Systems development Quality. Quality Management Journal. Vol 10, No. 4, pp. $39-54$.

Herawati Evi. 2008. Penggunaan Aplikasi SI untuk Perencanaan Persediaan pada PT. SS. Jurusan Komputerisasi Akuntansi, Fakultas Ilmu Komputer, Universitas Bina Nusantara. 
Igbaria M, 1997. An Examination of the factors contributing to Micro Computer techenology acceptance? . Journal of Information system, Elsiever Science, USA.

Ilma dan Sukoharsono. 2011. Analisis Penggunaan Internet untuk Pelaporan Bisnis pada Perusahaan Tambang yang Terdaftar di BEI. Vol 2, No 2 - Jurnal Ilmiah Mahasiswa FEB - Brawijaya .

Jogianto, Sisem Informasi Keprilakuan, Penerbit Andi Yogyakarta, 2007.yang Terdesentralisasi Terhadap Kinerja Organisasi. Thesis Unpad.

Kuang Hou. 2012. Examining the effect of user satisfaction on system usage and individual performance with business intelligence systems: An empirical study of Taiwan's electronics industr. International Journal of Information Management 32 (2012) 560573.

Limbu. 2014. Does information and communication technology improve job satisfaction? The moderating role of sales technology orientation. Industrial Marketing Management.

Mardjiono, Didik Eko. 2009. Analisis Pengaruh Kepemimpinan, Pemanfaatan Teknologi Informasi dan Implementasi Sistem Organisasi

Md. Dulal Hossain, Junghoon Moon, Jae-woong Yun , Young Chan Cho, 2011. Impact of psychological traits on pengguna performance in information systems delivering customer service: IS management perspective. Decision Support Systems 54 (2012) 270-281.

Muntianah, Siti Tutik. 2012. Pengaruh Minat Perilaku terhadap Actual Use Teknologi Informasi dengan Pendekatan TAM. Thesis Program Pasca Sarjana Universitas Brawijaya Malang.

Nazir, Moh. 2003. Metode Penelitian, Salemba Empat. Jakarta 63.

Norzaidi, Salwani. 2009. Evaluating Technology Resistance and Technology Satisfaction on Studet Performance. Campus wide Information System 26 (4), 298-312.
Oswari. Teddy. E. Susi Suhendra dan Ati Harmoni. (2008). Model perilaku penerimaan Teknologi Informasi Terhadap Produktivitas dan Usaha Kecil. Seminar ilmiah nasional komputasi dan sistem Intelegen (KOMMIT 2008). Universitas Gunadarma. Depok.

Radityo dan Zulaikha, 2007. Pengujian Model Delone and Maclean dalam Mengembangkan SIM (Kajian sebuah Kasus) Simposium Nasional Akuntansi 10 (SNA 10) Unhas Makasar.

Riduwan dan kuncoro. 2011. Analisis Path. Bandung Alfabetha.

Ristianti dan Sukoharsono. 2012. Web-Based Enterprise Resource Planning (ERP) Systems Implementation Analysis at PT. Anugrah Jasa Caterindo. Jurnal Ilmiah mahasiswa FEB. Vol 2. Universitas Brawijaya.

Schaupps. (2009). A conjoint analysis of online customer satisfaction. Journal of electronic commerce research Vol 6 no.2 University of North Carolina Wilmington.

Simamora. Manajemen SDM, Sekolah Tinggi Ilmu Ekonomi YKPN, Yogyakarta. 2004.

Singarimbun, M. dan Effendi, S., (2006). Metode Penelitian Survai, Cetakan Kedelapanbelas, Penerbit Pustaka LP3ES, Jakarta.

Singarimbun, Masri. 1995. Metode Penelititan Survei. LP3S, Jakarta

Solimun, et al. 2008. Pemodelan Persamaan Pendekatan PLS dan SEM. Fakultas MIPA. Pascasarjana Unbraw.

Sugiyono. 2012. Metode Penelitian Pendidikan Pendekatan Kuantitatif, Kualitatif, dan R\&D. Bandung: ALFABETA. 2012 (cet. 15)

Tempe, A.D. Seri Manajamen Sumber Daya Manusa : Kinerja, Elex Media Komputindo, Jakarta. 1992

Thompson Ronald, Howell, Higgins,.1991. Personal Computing : Toward a conceptual Model of Utilization? Management Information System Quarterly, 21(3).

Wibowo. 2010. Analisis Perilaku Pengguna Teknologi Informasi pada Perguruan Tinggi Berstatus BHMN. FPEB. Universitas Pendidikan Indonesia. 